\title{
Comparative Efficacy of Potassium Salts Against Soil-borne and Air-borne Fungi and Their Ability to Suppress Tomato Wilt and Fruit Rots
}

\author{
Jabnoun-Khiareddine $\mathbf{H}^{1 *}$, Abdallah $\mathbf{R}^{1,2}$, El-Mohamedy $\mathbf{R}^{3}$, Abdel-Kareem $\mathbf{F}^{3}$, Gueddes-Chahed $\mathbf{M}^{1}$, Hajlaoui A ${ }^{1}$ and Daami-Remadi $\mathbf{M}^{1}$ \\ ${ }^{1}$ UR13AGR09-Integrated Horticultural Production in the Tunisian Centre-East, Regional Center of Research on Horticulture and Organic Agriculture, University of Sousse, \\ Tunisia \\ ${ }^{2}$ National Agronomic Institute of Tunisia, 1082 Tunis Mahrajène, University of Carthage, Tunisia \\ ${ }^{3}$ Department of Plant Pathology, National Research Center, Dokki, Giza, Egypt
}

\begin{abstract}
Potassium sorbate (PS), potassium bicarbonate (PB) and dipotassium hydrogenphosphate (DPHP) were assessed for their antifungal activity against Fusarium oxysporum f. sp. lycopersici (FOL), F. oxysporum f. sp. radicis-lycopersici (FORL), F. solani, Verticillium dahliae (VD), Rhizoctonia solani, Colletotrichum coccodes, Pythium aphanidermatum, Sclerotinia sclerotiorum, Botrytis cinerea and Alternaria solani. They were screened for their ability to suppress Verticillium and Fusarium wilts, and Fusarium Crown and Root Rot (FCRR), for their effects on tomato growth, and for their potential control of Botrytis, Alternaria, Rhizoctonia and Anthracnose fruit rots. PS $(0.25-1.5 \%)$, DPHP (0.1-0.6 M) and PB (0.1-0.6 M) inhibited fungal growth in a concentration-dependent manner, with the greatest inhibition achieved using the highest concentrations. Inter specific variations in sensitivity were detected with $P$. aphanidermatum, $S$. Sclerotiorum and $B$. cinerea being the most sensitive to all salts. Single treatments using PS $(0.25 \%), \mathrm{PB}(50 \mathrm{mM})$ and DPHP $(50 \mathrm{mM})$ resulted in varied degree of protection against wilts. PS led to $50,78.26$ and $65 \%$ lower wilt severity as respectively compared to VD-, FOL- and FORL-inoculated controls. PS had significantly increased plant height, root and aerial part fresh weights by 20.61, 30.76 and $33.02 \%$, respectively, compared to FORL-inoculated plants and had improved root fresh weight by 42.18 and $32.87 \%$ compared to FOL-and VDinoculated plants, respectively. PB-based treatment led to 60.86 and $30 \%$ lower Fusarium wilt and FCRR severity but did not suppress Verticillium wilt. DPHP suppressed only Fusarium wilt by $65.21 \%$. Used as fruit treatment, DPHP and PS significantly decreased Botrytis, Rhizoctonia, Alternaria and Anthracnose fruit rots by 46.68 and $30.81 \%$, 14.04 and $15.74 \%, 20$ and $31.67 \%$, and 19.17 and $25.24 \%$, respectively, compared to inoculated and untreated controls. PB-based treatment resulted in $12.83 \%$ significantly lower Rhizoctonia fruit rot. These results showed that PS may be used as potential abiotic agent for successfully controlling fungal tomato diseases.
\end{abstract}

Keywords: Antifungal activity; Fruit rot; Potassium salts; Tomato pathogens; Wilt severity

\section{Introduction}

Fusarium wilt caused by Fusarium oxysporum f. sp. Lycopersici (FOL), Fusarium Crown and Root Rot (FCRR) incited by Fusarium oxysporum f. sp. radicis-lycopersici (FORL) and Verticillium wilt caused by Verticillium dahliae (VD) are among the most devastating tomato vascular diseases in Tunisia [1,2]. These soil-borne pathogens are economically important wilting pathogens in both greenhouse and open field-grown tomatoes in warm producing areas. In fact, yield losses up to 50 and $90 \%$ due to Verticillium wilt and FCRR disease, respectively, have been reported on severely infected tomato cultivars [1-3].

Management of these pathogens is difficult due not only to their endogenous growth, but also to the multi-years longevity of their resting structures in the soil (chlamydospores and microsclerotia) and to the inefficacy of fungicides once they reach the xylem [4-7]. Moreover, in Tunisia, tomato is regarded as one of the most important crops in terms of both value and cropped areas [8] and its continuous cropping leads to a buildup of fungal resting structures in the soil, resulting in substantial disease problems as well as the emergence of new races of these pathogens that overcome plant resistance [9-11]. For instance, the emergence of the race 2 of $V$. dahliae in Tunisia was recently reported and was shown to be involved in the outbreak of Verticillium wilt symptoms on resistant tomato cultivars [12]. That is why strategies developed for controlling these tomato diseases over years, such as cultural practices, chemical treatments, use of resistant cultivars, grafting, soil solarisation, biological control, etc., were often short lived and did not give satisfactory results. These strategies are either inefficient in reducing soil inoculum levels or harmful to the environment and human health [13].

In addition, as in Tunisia tomato is grown mainly in monoculture, wilt diseases are often associated with root rots and stem decay diseases caused by F. solani, Rhizoctonia solani, Colletotrichum coccodes, Pythium aphanidermatum and Sclerotinia sclerotiorum, which are reportedly responsible for severe growth reduction and yield losses. Moreover, the incidence of grey mold (Botrytis cinerea) and early blight (Alternari solani), which are among the most important diseases of tomato aerial parts both in greenhouse or open field crops leading to lower quantity and quality of fruit yields, is in constant increase [14,15].

The increasingly important economic impact of these pathogens together with the absence of curative treatments justifies increased

*Corresponding author: Jabnoun-Khiareddine H, UR13AGR09-Integrated Horticultural Production in the Tunisian Centre-East, Regional Center of Research on Horticulture and Organic Agriculture, University of Sousse, Tunisia, Tel: +216 73368 125; E-mail: jkhayfa@yahoo.fr

Received January 06, 2016; Accepted February 06, 2016; Published February 13, 2016

Citation: Jabnoun-Khiareddine H, Abdallah R, El-Mohamedy R, Abdel-Kareem F Gueddes-Chahed M, et al. (2016) Comparative Efficacy of Potassium Salts Against Soil-borne and Air-borne Fungi and Their Ability to Suppress Tomato Wilt and Fruit Rots. J Microb Biochem Technol 8: 045-055. doi:10.4172/1948-5948.1000261

Copyright: (c) 2016 Jabnoun-Khiareddine H, et al. This is an open-access article distributed under the terms of the Creative Commons Attribution License, which permits unrestricted use, distribution, and reproduction in any medium, provided the original author and source are credited. 
Citation: Jabnoun-Khiareddine H, Abdallah R, El-Mohamedy R, Abdel-Kareem F, Gueddes-Chahed M, et al. (2016) Comparative Efficacy of Potassium Salts Against Soil-borne and Air-borne Fungi and Their Ability to Suppress Tomato Wilt and Fruit Rots. J Microb Biochem Technol 8: 045055. doi:10.4172/1948-5948.1000261

attention to search for alternative methods for tomato diseases' management. An interesting alternative to chemical control involves the use of the antimicrobial properties of some organic and inorganic salts, generally used in food processing and preservation, to control plant diseases [16-18].

Several organic and inorganic salts have been widely used for suppression of fungal pathogens on various crops (open field and protected) responsible for various diseases on different plant organs and growth stages [19]. Importantly, these salts have a broad spectrum of antimicrobial activity with low mammalian toxicity, possess biocompatibility $[16,17]$, and are generally recognized as safe (GRAS). Thus, they are widely exploited in food industry as preservatives, $\mathrm{pH}$ regulators and antimicrobial agents [17].

Potassium bicarbonates and carbonates have been demonstrated to inhibit the growth of several fungal pathogens infecting vegetables and ornamental crops at the post-harvest phase [17,20-22]. In the same manner, foliage spays of sodium or potassium bicarbonates led to decreased powdery mildew severity (Leveillula taurica) in pepper plants [23]. These salts were eventually registered as pesticide ingredients in the USA and as a horticultural fungicide in the UK $[19,24]$ and they exhibit antifungal properties when applied as foliar sprays at concentrations between 5 and $20 \mathrm{~g} / \mathrm{l}$ [19]. Multiple mechanisms are possibly involved in the registered antifungal effect of bicarbonate salts, such as $\mathrm{pH}$ elevation on the leaf surface [25] and collapse of fungal cell walls due to $\mathrm{K}^{+}$imbalance or dehydration of fungal spores [26]. In addition to its potential to reduce the environmental impact of synthetic fungicides, potassium bicarbonate (PB) has lower risk of fungal resistance development due to its multiple modes of action, lower cost and shorter application to harvest interval [26].

Dipotassium hydrogenphosphate (DPHP) is among the most studied phosphate salts for their antifungal properties [19]. Reuveni et al., [27] described phosphates as ideal candidates for fungal disease management as they are fast absorbed by the plant, they have high mobility within tissues and have low cost nutrient source. Furthermore, phosphates exhibit antifungal activity through the induction of systemic acquired resistance; thus, providing long-lasting plant protection and are also effective against many fungal pathogens [19].

Potassium sorbate (PS) is a weak acid exhibiting antimicrobial as well as antifungal, activity $[28,29]$. PS was among the most effective compounds used for the control of orange molds caused by Penicillium digitatum and $P$. italicum and for the management of several foodborne fungal pathogens [30,31].

Therefore, the objectives of the present work were to (i) evaluate the in vitro antifungal activity of potassium salts against ten tomato pathogens responsible for wilts, crown and root rots, stem decay and fruit rots, (ii) to assess their suppressive effects of Verticillium and Fusarium wilts, (iii) to elucidate their impacts on tomato growth, under growth chamber conditions and (iv) to investigate their suppressive effects on fruit rots' severity.

\section{Materials and Method}

\section{Plant material}

Tomato seeds (cv. Rio Grande) were superficially disinfected by immersion in absolute ethanol for $2 \mathrm{~min}$, followed by extensive rinsing in sterile distilled water. Seeds were sown in alveolus plates filled with previously sterilized peat. Seedlings were grown in a growth chamber at $24-26^{\circ} \mathrm{C}$ with $12-\mathrm{h}$ photoperiod and $70 \%$ relative humidity. They were watered daily and fertilized once a week with a standard nutrient solution according to Pharand et al. [32]. Experiments were performed using 30 days-old tomato plants.

\section{Fruit material}

Tomato (cv. Sahel) fruits were harvested at the firm-mature red stage and sorted based on size and the absence of physical injuries or apparent disease infection. Before treatments, fruits were surfacedisinfected with $2 \%$ sodium hypochlorite for $3 \mathrm{~min}$, then rinsed with sterile distilled water, and air-dried.

\section{Fungal pathogens}

The fungal pathogens used in this study were: FOL, FORL, F. solani, VD, C. coccodes, R. solani, P. aphanidermatum, S. sclerotiorum, B. cinerea, and A. solani. These pathogens were isolated from roots, crowns, stems, leaves and fruits of diseased tomato plants and were held in the fungal culture collection of the laboratory of Phytopathology in the Regional Center of Research on Horticulture and Organic Agriculture of Chott Mariem-Tunisia. Cultures of each fungus were maintained on Potato Dextrose Agar (PDA; Difco, Detroit, MI, USA) and were stored in PDA slants at $5^{\circ} \mathrm{C}$ until further use.

Liquid cultures used for substrate inoculation were prepared on Potato Dextrose Broth (PDB) and incubated at $25^{\circ} \mathrm{C}$ under continuous shaking at $150 \mathrm{rpm}$ during 4 to 5 days. Concentration of the conidial suspension used was adjusted to $10^{7}$ conidia/ml using a Malassez haemocytometer.

\section{Potassium salts tested}

Potassium salts used in this study and their respective chemical characteristics are given in Table 1. PS was tested at concentrations of $0.25,0.5,1$, and $1.5 \%(\mathrm{v} / \mathrm{v})$ while DPHP and PB were tested at $0.1,0.4$, and $0.6 \mathrm{M}$.

\section{In vitro antifungal activity of potassium salts against tomato pathogens}

The inhibitory effect of potassium salts on the mycelial growth of tomato pathogens was evaluated on PDA medium supplemented with streptomycin sulfate $(300 \mathrm{mg} / \mathrm{l})$. The desired quantities of the tested salts were added to autoclaved and molten PDA to achieve the targeted concentrations tested. For each compound, a $10 \mathrm{ml}$ aliquot of amended PDA was aseptically poured into a Petri plate $(9 \mathrm{~cm}$ in diameter), with an unamended PDA dish used as a control. Three agar plugs $(6 \mathrm{~mm}$ in diameter) cut from 7-day-old fungal cultures were plated at $2 \mathrm{~cm}$ from the edge of the plate and equidistantly spaced from each other by $3 \mathrm{~cm}$. Plates were sealed with parafilm and incubated in the dark at

\begin{tabular}{|l|l|l|l|}
\hline Compound & Chemical formule & Molecular weight & Company \\
\hline Potassium sorbate (PS) & $\mathrm{C}_{6} \mathrm{H}_{7} \mathrm{KO}_{2}$ & $150.22(\mathrm{~g} / \mathrm{mol})$ & Loba Chemie, (Mumbai, India) \\
\hline Potassium bicarbonate (PB) & $\mathrm{KHCO}_{3}$ & $100.12(\mathrm{~g} / \mathrm{mol})$ & Loba Chemie, (Mumbai, India) \\
\hline Dipotassium hydrogen phosphate (DPHP) & $\mathrm{K}_{2} \mathrm{HPO}_{4}$ & $174.20(\mathrm{~g} / \mathrm{mol})$ & Suvchem, (Maharashtra, India) \\
\hline
\end{tabular}

Table 1: Potassium salts tested in this study. 
Citation: Jabnoun-Khiareddine H, Abdallah R, El-Mohamedy R, Abdel-Kareem F, Gueddes-Chahed M, et al. (2016) Comparative Efficacy of Potassium Salts Against Soil-borne and Air-borne Fungi and Their Ability to Suppress Tomato Wilt and Fruit Rots. J Microb Biochem Technol 8: 045055. doi:10.4172/1948-5948.1000261

$25^{\circ} \mathrm{C}$ for varying times depending on growth rate of each organism and time necessary for reaching the edge of the plate. This was as briefly as 1 day for fast-growing organisms like P. aphanidermatum and as long as 7 days for slower growing ones like VD. Colony diameters were measured at two perpendicular points and the mean was determined. The mycelial growth inhibition percentage was calculated according to the formula of Tiru M et al., as follows: $I \%=[(C 2-C 1) / C 2] \times 100$ with C2: Mean pathogen colony diameter in control plates and C1: Mean pathogen colony diameter in presence of tested compounds [33]. The experiment was repeated twice, with three replicates per individual treatment.

Statistical analyses were performed, for each salt tested, following a completely randomized factorial design where pathogens and salts concentrations were the two fixed factors. Six replicates were used per individual treatment and means were separated using Fisher's protected LSD or Duncan's Multiple Range tests (at $P \leq 0.05$ ). The whole experiment was repeated twice but only the data of one essay is presented in the present study. Statistical analyses were performed using SPSS software version 16.

\section{Effect of potassium salts on tomato wilt severity under growth chamber conditions}

PS $(0.25 \%, v / v)$, PB $(50 \mathrm{mM})$ and DPHP $(50 \mathrm{mM})$ were tested in vivo, as foliar spray, for controlling Verticillium wilt, Fusarium wilt and FCRR. These salts' concentrations were chosen as the optimal ones for in vivo experiments without any significant phytotoxic effects [34].

At 30 days-old, tomato seedlings (cv. Rio Grande) were sprayed with $50 \mathrm{ml}$ of each salt aqueous solution using a hand sprayer. This quantity was sufficient to ensure complete coverage of all plant surfaces. Plants sprayed with distilled water only served as untreated controls. Five days post-treatment, seedlings were carefully removed from alveolus plates and re-potted in peat contained in $17 \mathrm{~cm}$ diameter-pot and were watered by $100 \mathrm{ml}$ of each fungal conidial suspension (pathogen challenge), as close as possible to the root system.

For each individual treatment, five plants were used and the experiment was repeated twice. Five un- inoculated and untreated plants and five inoculated and untreated others were used as controls.

All tomato plants were maintained in a growth chamber at $15-30^{\circ} \mathrm{C}$ during 60 days and regularly watered and fertilized with a standard nutrient solution according to Tiru et al. [33].

Assessment of disease severity was performed 60 days postinoculation (DPI) on tomato plants challenged with pathogens (VD, FOL and FORL) using a disease index recorded based on wilt and leaf yellowing intensity using an arbitrary 0-5 scale where $0=$ no symptoms, $1=1-25 \%$ plant wilting and yellowing; $2=26-50 \%$ wilting and yellowing; $3=51-75 \%$ wilting and yellowing; $4=76-99 \%$ and $5=$ dead plant. Furthermore, plant height and root and aerial part fresh weights were noted for all tomato plants.

For all parameters measured, statistical analyses were performed for each pathogen used (VD, FOL and FORL) following a completely randomized design where treatments (potassium salts tested, inoculated and untreated control and the uninoculated and untreated control) represented the only fixed factor. Five replicates were used per individual treatment and means were separated using Duncan's Multiple Range test (at $P \leq 0.05$ ). Statistical analyses were performed using SPSS software version 16.

\section{Effect of potassium salts on tomato fruit rots' severity}

A bioassay on tomato fruits was carried out to evaluate the ability of PS $(0.1 \%, \mathrm{v} / \mathrm{v}), \mathrm{PB}(0.4 \mathrm{M})$ and DPHP $(0.4 \mathrm{M})$ to suppress tomato fruit rots caused by B. cinerea, $A$. solani, $C$. coccodes and $R$. solani. For this purpose, disinfected tomato fruits were wounded (4 $\mathrm{mm}$ deep and $6 \mathrm{~mm}$ in diameter) using a sterile cork borer at the equator and $100 \mu \mathrm{l}$ of each of the salt solution, or sterile distilled water for the untreated control, were injected into each wound. After $6 \mathrm{~h}$, a mycelial plug (6 $\mathrm{mm}$ in diameter) of each of the tested pathogens was deposited in each wound. Treated fruits were placed on moist filter papers in plastic boxes to maintain a high relative humidity (about $95 \%$ ) and stored at $25^{\circ} \mathrm{C}$. Disease symptoms were evaluated by determining the average lesion diameter 5 days post-inoculation by $B$. cinerea and $R$. solani and 7 days post $A$. solani and $C$. coccodes challenge. Each individual treatment was repeated thrice using 5 fruits per replication.

\section{Results}

\section{In vitro evaluation of the antifungal activity of potassium salts against tomato pathogens}

For each salt tested, ANOVA analysis revealed a significant (at $P$ $\leq 0.01$ ) variation in the average fungal colony diameter depending on tomato pathogens tested and potassium salts' concentrations used.

Data shown in Table 2 indicated that in PS-amended PDA, mycelial growth inhibition of all pathogens varied in a concentration-dependent manner with $100 \%$ inhibition recorded at concentrations above $0.25 \%$. Linear growth of tested fungi decreased significantly with the increase of PS concentrations. In fact, as compared to the untreated control, inhibition of mycelial growth (combined data of all fungi tested) ranged from 23.26 to $100 \%$ using PS at $0.25 \%$ compared to $51.92-100 \%$ and $57.84-100 \%$, achieved using this salt at 0.5 and $1 \%$. However, at the highest concentration, $1.5 \%$, PS had completely suppressed pathogens' radial growth.

Tomato pathogens exhibited variable responses when grown on PDA amended with different PS concentrations (Table 2). In fact, increasing PS concentration from 0.25 to $1 \%$ resulted in 25.75 69.03\% and $23.69-57.84 \%$ decrease in FOL and FORL mycelial growth, respectively. However, this salt had totally suppressed the in vitro growth of $P$. aphanidermatum, $S$. sclerotiorum and $B$. cinerea at the lowest concentration used $(0.25 \%)$. F. solani, $R$. solani, C. coccodes and VD were inhibited by $26.80,53.67,23.26$ and $60.91 \%$, respectively, using PS at $0.25 \%$ and were totally suppressed using this salt at $0.5 \%$. A. solani radial growth decreased by 22.87 and $73.26 \%$ using PS at 0.25 and $0.5 \%$, respectively, and was completely suppressed at higher concentrations (1 and 1.5\%).

As given in Table 3, PB inhibited mycelial growth of all pathogens grown in amended-PDA medium in a concentration-dependent manner and the greater inhibitory effect was recorded at the highest concentrations used. In fact, this salt reduced pathogens' growth (combined data of all fungi tested) by $0.39-100 \%$ at $0.1 \mathrm{M}$ compared to 7.09-100\% and 55.04-100\% decrease achieved using PB at 0.4 and 0.6 $\mathrm{M}$, respectively.

When grown on PDA medium amended with $\mathrm{PB}$ at 0.1 to $0.6 \mathrm{M}$, mycelial growth of FOL, FORL and $F$. solani was inhibited from $3.36 \%$ $77.99 \%, 7.41 \%-62.55 \%$, and $2.29 \%-47.71 \%$, respectively, compared to $21.85 \%-89.28 \%, 31.40 \%-55.04 \%$ and $8.12 \%-57.36 \%$ decrease, compared to the untreated controls, noted on $R$. solani, C. coccodes and VD treated cultures, respectively. For A. solani, these inhibition 
Citation: Jabnoun-Khiareddine H, Abdallah R, El-Mohamedy R, Abdel-Kareem F, Gueddes-Chahed M, et al. (2016) Comparative Efficacy of Potassium Salts Against Soil-borne and Air-borne Fungi and Their Ability to Suppress Tomato Wilt and Fruit Rots. J Microb Biochem Technol 8: 045055. doi:10.4172/1948-5948.1000261

\begin{tabular}{|c|c|c|c|c|c|c|}
\hline \multirow[b]{2}{*}{ Fungi tested } & \multirow[b]{2}{*}{0} & \multicolumn{5}{|c|}{ Potassium sorbate (PS) concentration $(\%, v / v)$} \\
\hline & & 0.25 & 0.5 & 1 & 1.5 & $\begin{array}{l}\text { Average per } \\
\text { fungus tested } \mathrm{d}^{*}\end{array}$ \\
\hline Fusarium oxysporum f. sp. lycopersici & 4.47 & 3.32 & 1.85 & 1.38 & 0 & $2.20 \mathrm{~b}$ \\
\hline F. oxysporum f. sp. radicis-lycopersici & 4.78 & 3.65 & 2.30 & 2.02 & 0 & $2.55 \mathrm{a}$ \\
\hline F. solani & 4.85 & 3.55 & 0 & 0 & 0 & $1.68 \mathrm{c}$ \\
\hline Verticillium dahliae & 3.28 & 1.28 & 0 & 0 & 0 & $0.91 \mathrm{f}$ \\
\hline Colletotrichum coccodes & 4.30 & 3.30 & 0 & 0 & 0 & $1.52 \mathrm{~d}$ \\
\hline Rhizoctonia solani & 4.82 & 2.23 & 0 & 0 & 0 & $1.41 \mathrm{e}$ \\
\hline Sclerotinia sclerotiorum & 4.97 & 0 & 0 & 0 & 0 & $0.99 \mathrm{f}$ \\
\hline Pythium aphanidermatum & 4.40 & 0 & 0 & 0 & 0 & $0.88 \mathrm{f}$ \\
\hline Botrytis cinerea & 4.67 & 0 & 0 & 0 & 0 & $0.93 \mathrm{f}$ \\
\hline Alternaria solani & 4.30 & 3.32 & 1.15 & 0 & 0 & $1.75 \mathrm{c}$ \\
\hline Average per potassium sorbate concentration ${ }^{\mathrm{b}^{*}}$ & $4.48 \mathrm{a}$ & $2.07 \mathrm{~b}$ & $0.53 \mathrm{c}$ & $0.34 \mathrm{~d}$ & $0 \mathrm{e}$ & \\
\hline \multicolumn{7}{|c|}{$\begin{array}{l}\text { LSD (Fungal pathogens } \mathrm{x} \text { potassium sorbate concentrations) }=0.549 \mathrm{~cm} \text { at } P \leq 0.05 \text {. } \\
\text { a Mean mycelial growth per fungal pathogen for all potassium sorbate concentrations combined. } \\
\text { b Mean mycelial growth per potassium sorbate concentration tested for all fungal pathogens combined. } \\
\text { 'For fungal pathogens and potassium sorbate concentrations tested, values (means) followed by the same letter are not significantly different according to Duncan's } \\
\text { Multiple Range test at } P \leq 0.05 \text {. } \\
\text { Pathogens were cultured on PDA medium and incubated at } 25^{\circ} \mathrm{C} \text { for } 1 \mathrm{~d}(P \text {. aphanidermatum), } 2 \mathrm{~d}(R \text {. solani and } S \text {. sclerotiorum), } 3 \mathrm{~d}(B \text {. cinerea, FOL, FORL and } F \text {. } \\
\text { solani), } 4 \mathrm{~d}(A \text {. solani and } C \text {. coccodes) and } 7 \mathrm{~d}(\mathrm{VD}) \text {. }\end{array}$} \\
\hline
\end{tabular}

Table 2: Effect of different potassium sorbate $\left(\mathrm{C}_{6} \mathrm{H}_{7} \mathrm{KO}_{2}\right)$ concentrations on the in vitro mycelial growth of tomato fungal pathogens cultured at $25^{\circ} \mathrm{C}$ on $\mathrm{PDA}$ medium.

\begin{tabular}{|c|c|c|c|c|c|}
\hline \multirow[b]{2}{*}{ Fungi tested } & \multicolumn{5}{|c|}{ Potassium bicarbonate (PB) concentration (M) } \\
\hline & 0 & 0.1 & 0.4 & 0.6 & Average per fungus tested ${ }^{\mathrm{a}^{*}}$ \\
\hline Fusarium oxysporum f. sp. lycopersici & 4.47 & 4.32 & 4.15 & 0.98 & $3.47 \mathrm{a}$ \\
\hline F. oxysporum f. sp. radicis-lycopersici & 4.78 & 4.53 & 3.90 & 1.07 & $3.57 \mathrm{a}$ \\
\hline F. solani & 4.85 & 4.40 & 4.33 & 1.02 & $3.65 \mathrm{a}$ \\
\hline Verticillium dahliae & 3.28 & 3.02 & 1.60 & 1.40 & $2.32 \mathrm{c}$ \\
\hline Colletotrichum coccodes & 4.30 & 2.95 & 2.40 & 1.93 & $2.89 \mathrm{~b}$ \\
\hline Rhizoctonia solani & 4.82 & 3.77 & 0.60 & 0.52 & $2.43 \mathrm{c}$ \\
\hline Sclerotinia sclerotiorum & 4.97 & 0 & 0 & 0 & $1.24 \mathrm{~d}$ \\
\hline Pythium aphanidermatum & 4.40 & 0 & 0 & 0 & $1.10 \mathrm{~d}$ \\
\hline Botrytis cinerea & 4.67 & 0 & 0 & 0 & $1.16 \mathrm{~d}$ \\
\hline Alternaria solani & 4.30 & 4.28 & 3.22 & 0.13 & $2.98 \mathrm{~b}$ \\
\hline Average per potassium bicarbonate concentration ${ }^{\mathrm{b}^{*}}$ & $4.48 \mathrm{a}$ & $2.72 \mathrm{~b}$ & $2.02 \mathrm{c}$ & $0.70 \mathrm{~d}$ & \\
\hline \multicolumn{6}{|c|}{$\begin{array}{l}\text { LSD (Fungal pathogens } \mathrm{x} \text { potassium bicarbonate concentrations) }=0.226 \mathrm{~cm} \text { at } P \leq 0.05 \text {. } \\
\text { a Mean mycelial growth per fungal pathogen for all potassium bicarbonate concentrations combined. } \\
\text { b Mean mycelial growth per potassium bicarbonate concentration tested for all fungal pathogens combined. } \\
\text { "For fungal pathogens and potassium bicarbonate concentrations tested, values (means) followed by the same letter are not significantly different according to Duncan's } \\
\text { Multiple Range test at } P \leq 0.05 \text {. } \\
\text { Pathogens were cultured on PDA medium and incubated at } 25^{\circ} \mathrm{C} \text { for } 1 \mathrm{~d}(P \text {. aphanidermatum), } 2 \mathrm{~d}(R \text {. solani and } S \text {. sclerotiorum), } 3 \mathrm{~d}(B \text {. cinerea, FOL, FORL and } F \text {. } \\
\text { solani), } 4 \mathrm{~d}(A \text {. solani and } C \text {. coccodes) and } 7 \mathrm{~d}(\mathrm{VD}) \text {. }\end{array}$} \\
\hline
\end{tabular}

Table 3: Effect of different potassium bicarbonate $\left(\mathrm{KHCO}_{3}\right)$ concentrations on the in vitro mycelial growth of tomato fungal pathogens cultured at $25^{\circ} \mathrm{C}$ on $\mathrm{PDA}$ medium.

rates ranged between 0.39 and $96.90 \%$ while growth of $B$. cinerea was totally suppressed using the lowest $\mathrm{PB}$ concentration $(0.1 \mathrm{M}) . P$. aphanidermatum and S. sclerotiorum were found to be the most sensitive among the fungi tested as their growth was completely inhibited using all tested PB concentrations.

Results presented in Table 4 showed clearly that in DPHP-amended PDA, pathogens' linear growth varied in a dose-related manner by decreasing significantly with the increase of DPHP concentrations. In fact, tomato pathogens' mycelial growth (combined data of all fungi tested) was reduced by $0.37 \%-60.71 \%$ at $0.1 \mathrm{M}$ DPHP compared to $3.36 \%-100 \%$ and $23.26 \%-100 \%$ recorded using this salt at 0.4 and 0.6 $\mathrm{M}$, respectively.

Moreover, when DPHP concentrations increased from 0.1 to $0.6 \mathrm{M}$, the inhibition of FOL, FORL and F. solani radial growth augmented from 0.37 to $36.57 \%$, from 5.92 to $37.98 \%$, and from $6.87 \%$ to $48.80 \%$, respectively. However, for R. solani, C. coccodes and $\mathrm{VD}$, these inhibition rates ranged between $2.49 \%-75.45 \%, 3.49 \%$ -
$23.26 \%$, and $13.71 \%-42.64 \%$, respectively. With the increase of DPHP concentrations, mycelial growth of $A$. solani was also reduced by $4.26 \%-78.68 \%$ compared to $6.38 \%-100 \%, 60.71 \%-100 \%$ and $3.03 \%-$ $100 \%$ noted for S. sclerotiorum, B. cinerea and P. aphanidermatum, respectively. Thus, these three last pathogens were the most sensitive fungal species to DPHP as their radial growth was completely suppressed at $0.4 \mathrm{M}$.

\section{Effect of potassium salts on verticillium and fusarium wilts severity under growth chamber conditions}

The three potassium salts, applied as foliar spray 5 days before single inoculation with three soil-borne fungi (VD, FOL and FORL), was evaluated for their effects on wilt severity and plant growth in comparison to untreated and inoculated or non-controls.

\section{Wilt severity}

All pathogen-inoculated tomato plants showed 60 DPI typical wilt 
Citation: Jabnoun-Khiareddine H, Abdallah R, El-Mohamedy R, Abdel-Kareem F, Gueddes-Chahed M, et al. (2016) Comparative Efficacy of Potassium Salts Against Soil-borne and Air-borne Fungi and Their Ability to Suppress Tomato Wilt and Fruit Rots. J Microb Biochem Technol 8: 045055. doi:10.4172/1948-5948.1000261

\begin{tabular}{|c|c|c|c|c|c|c|c|}
\hline \multirow[b]{2}{*}{ Fungi tested } & \multicolumn{7}{|c|}{ Dipotassium hydrogenphosphate (DPHP) concentration (M) } \\
\hline & \multicolumn{2}{|c|}{0} & 0.1 & \multicolumn{2}{|c|}{0.4} & 0.6 & Average per fungus tested $\mathrm{a}^{*}$ \\
\hline Fusarium oxysporum f. sp. lycopersici & \multicolumn{2}{|l|}{4.47} & 4.45 & \multicolumn{2}{|l|}{4.32} & 2.83 & $4.02 \mathrm{ab}$ \\
\hline F. oxysporum f. sp. radicis-lycopersici & \multicolumn{2}{|l|}{4.78} & 4.50 & \multicolumn{2}{|l|}{4.28} & 2.97 & $4.13 \mathrm{a}$ \\
\hline F. solani & \multicolumn{2}{|l|}{4.85} & 4.52 & \multicolumn{2}{|l|}{4.30} & 2.48 & $4.04 \mathrm{ab}$ \\
\hline Verticillium dahliae & \multicolumn{2}{|l|}{3.28} & 2.83 & \multicolumn{2}{|l|}{2.50} & 1.88 & $2.62 \mathrm{e}$ \\
\hline Colletotrichum coccodes & \multicolumn{2}{|l|}{4.30} & 4.15 & \multicolumn{2}{|l|}{3.50} & 3.30 & $3.81 \mathrm{bc}$ \\
\hline Rhizoctonia solani & \multicolumn{2}{|l|}{4.82} & 4.70 & \multicolumn{2}{|l|}{4.27} & 1.18 & $3.74 \mathrm{c}$ \\
\hline Sclerotinia sclerotiorum & \multicolumn{2}{|l|}{4.97} & 4.65 & \multicolumn{2}{|l|}{0} & 0 & $2.40 \mathrm{f}$ \\
\hline Pythium aphanidermatum & \multicolumn{2}{|l|}{4.40} & 4.27 & \multicolumn{2}{|l|}{0} & 0 & $2.16 \mathrm{~g}$ \\
\hline Botrytis cinerea & \multicolumn{2}{|l|}{4.67} & 1.83 & \multicolumn{2}{|l|}{0} & 0 & $1.62 \mathrm{~h}$ \\
\hline Alternaria solani & \multicolumn{2}{|l|}{4.30} & 4.12 & \multicolumn{2}{|l|}{2.80} & 0.92 & $3.03 \mathrm{~d}$ \\
\hline Average per potassium phosphate concentration ${ }^{b^{*}}$ & $4.48 \mathrm{a}$ & & $4.00 \mathrm{~b}$ & $2.59 \mathrm{c}$ & & $1.55 \mathrm{~d}$ & \\
\hline $\begin{array}{l}\text { LSD (Fungal pathogens } x \text { potassium phosphate co } \\
\text { a Mean mycelial growth per fungal pathogen for all } \\
\text { b Mean mycelial growth per potassium phosphate } \\
\text { * For fungal pathogens and potassium phosphate c } \\
\text { Multiple Range test at } P \leq 0.05 \text {. } \\
\text { Pathogens were cultured on PDA medium and inc } \\
\text { solani), } 4 \mathrm{~d} \text { (A. solani and } C \text {. coccodes) and } 7 \mathrm{~d}(\mathrm{~V}\end{array}$ & $\begin{array}{l}\text { at } P \leq 0 \text {. } \\
\text { רcentrati } \\
\text { I fungal } \\
\text { ues (me } \\
\text { aphan }\end{array}$ & $\begin{array}{l}\text { ns comb } \\
\text { athogen } \\
\text { ns) follo } \\
\text { dermatu }\end{array}$ & $\begin{array}{l}\text { ined. } \\
\text { wed by } t \\
\text { w), } 2 \mathrm{~d}(\end{array}$ & $\begin{array}{l}\text { me lette } \\
\text { lani and }\end{array}$ & S. sc & ot signif & $\begin{array}{l}\text { y different according to Dunca } \\
\text { d (B. cinerea, FOL, FORL and }\end{array}$ \\
\hline $\begin{array}{l}\text { Table 4: Effect of different Dipotassium hydrogenph } \\
\text { medium. }\end{array}$ & ntratio & on the & in vitro $\mathrm{m}$ & 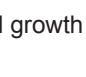 & tortot & lato fung & thogens cultured at $25^{\circ} \mathrm{C}$ on $\mathrm{P}$ \\
\hline Treatment / Pathogen & & Diseas & e index & & & & \\
\hline & & VD & & & FOL & & FORL \\
\hline Potassium sorbate (PS) & & $1.6 \mathrm{~b}$ & & & $1 \mathrm{bc}$ & & $1.4 \mathrm{c}$ \\
\hline Potassium bicarbonate (PB) & & $2.8 \mathrm{ab}$ & & & $1.8 \mathrm{~b}$ & & $2.8 \mathrm{~b}$ \\
\hline Dipotassium hydrophosphate (DPHP) & & $3 \mathrm{a}$ & & & $1.6 \mathrm{~b}$ & & $3 a b$ \\
\hline Inoculated control & & $3.2 \mathrm{a}$ & & & $4.6 \mathrm{a}$ & & $4 \mathrm{a}$ \\
\hline Uninoculated control & & $0 \mathrm{c}$ & & & $0 \mathrm{c}$ & & $0 \mathrm{~d}$ \\
\hline
\end{tabular}

Table 5: Effect of potassium salt-based treatments on disease severity on tomato cv. Rio Grande plants inoculated with Verticillium dahliae (VD), Fusarium oxysporum $\mathrm{f}$ sp. lycopersici (FOL) and F. oxysporum f. sp. radicis-lycopersici (FORL) noted 60 days post-inoculation under growth chamber conditions.

Potassium sorbate $(0.25 \%, \mathrm{v} / \mathrm{v})$, potassium bicarbonate $(50 \mathrm{mM})$ and potassium phosphate $(50 \mathrm{mM})$ were applied as foliar spray five days before inoculation. Wilt severity was assessed based on $0-5$ scale (where $0=$ no symptoms and $5=$ dead plant).

symptoms while uninoculated and untreated ones were symptomless. However, for each pathogen, wilt severity varied significantly (at $P \leq$ 0.05) depending on treatments tested (Table 5).

Verticillium wilt severity noted on PS-treated plants was significantly reduced by $50 \%$ compared to VD-inoculated and untreated control ones. Foliar spray with PB led to $12.5 \%$ reduction in wilt severity even statistically comparable to the VD-inoculated and untreated control and also similar to PS-based treatment. DPHP-based treatment did not provide any protection against Verticillium wilt severity which was comparable to that of VD-inoculated and untreated control.

PS-based treatment provided the highest protection against Fusarium wilt and led to $78.26 \%$ significantly lower disease severity, as compared to FOL-inoculated and untreated control and exhibited comparable effectiveness as the two other salts. PB and DPHP spray decreased Fusarium wilt severity by $60.86 \%$ and $65.21 \%$, respectively, compared to FOL-inoculated and untreated control.

Varied degree of protection of tomato plants against FCRR was recorded with foliar application of the tested potassium salts. In fact, PS- and PB-based treatment had significantly reduced disease severity by $65 \%$ and $30 \%$ as compared to FORL-inoculated and untreated control. DPHP-treated plants showed 25\% lower disease severity, even statistically insignificant, than that noted on FORL-inoculated and untreated control plants but significantly comparable to that of PB-treated plants. Foliar application of PS provided 53.33 and 50\% greater protection against FCRR severity than DPHP- and PB-based treatments.

\section{Plant height}

Plant height noted 60 DPI on PS-, PB- and DPHP-treated plants was significantly (at $P \leq 0.05$ ) comparable to that noted on their respective VD- and FOL-inoculated or non-controls (Table 6). However, compared to FORL-inoculated plants, these treatments had significantly increased plant height by $20.61 \%, 19.55 \%$ and $9.5 \%$, respectively. Plant heights noted on PS- and PB-treated plants were statistically similar and significantly higher than that of DPHP-treated plants but also comparable to that of the untreated and uninoculated control. Plant height noted on DPHP-treated plants was $14.16 \%$ lower than that of the untreated and uninoculated control.

\section{Root fresh weight}

Root fresh weight noted 60 DPI on tomato plants varied significantly (at $\mathrm{P} \leq 0.05$ ) depending on treatments tested. Indeed, data given in Table 7 showed that PS- and PB-based treatment had significantly increased root fresh weight by $32.87 \%$ and $27.94 \%$ compared to VDinoculated plants and were statistically comparable to the untreated and uninoculated control. Root fresh weight noted on DPHP-treated plants was comparable to both controls.

Root fresh weight noted on PS-treated plants was significantly $42.18 \%$ higher than that of FOL-inoculated plants and statistically comparable to that of the untreated and uninoculated control. This parameter noted on PB-treated plants was increased by $28.84 \%$, even statistically insignificant, in comparison to FOL-inoculated and untreated control but was comparable to that noted on PS- and DPHP- 
Citation: Jabnoun-Khiareddine H, Abdallah R, El-Mohamedy R, Abdel-Kareem F, Gueddes-Chahed M, et al. (2016) Comparative Efficacy of Potassium Salts Against Soil-borne and Air-borne Fungi and Their Ability to Suppress Tomato Wilt and Fruit Rots. J Microb Biochem Technol 8: 045055. doi:10.4172/1948-5948.1000261

\begin{tabular}{|l|l|l|l|}
\hline Treatment / Pathogen & Plant height (cm) & \multicolumn{2}{l|}{} \\
\cline { 2 - 3 } & VD & FOL \\
\hline Potassium sorbate (PS) & $47.8 \mathrm{a}$ & $45.6 \mathrm{a}$ \\
\hline Potassium bicarbonate (PB) & $46.2 \mathrm{a}$ & $47 \mathrm{a}$ \\
\hline Dipotassium hydrophosphate (DPHP) & $46 \mathrm{a}$ & $51.4 \mathrm{a}$ \\
\hline Inoculated control & $44 \mathrm{a}$ & $45.6 \mathrm{a}$ \\
\hline Uninoculated control & $46.8 \mathrm{a}$ & $45 \mathrm{a}$ \\
\hline${ }^{*}$ For each pathogen tested, values (means) followed by the same letter are not significantly different according to Duncan's Multiple Range test at $P \leq 0.05$. & $40 \mathrm{~b}$ \\
\hline
\end{tabular}

*For each pathogen tested, values (means) followed by the same letter are not significantly different according to Duncan's Multiple Range test at $P \leq 0.05$.

Table 6: Effect of potassium salt-based treatments on height of tomato cv. Rio Grande plants inoculated with Verticillium dahliae (VD), Fusarium oxysporum f. sp. lycopersici (FOL) and F. oxysporum f. sp. radicis-lycopersici (FORL) noted 60 days post-inoculation under growth chamber conditions.

Potassium sorbate $(0.25 \%, v / v)$, potassium bicarbonate $(50 \mathrm{mM})$ and potassium phosphate $(50 \mathrm{mM})$ were applied as foliar spray five days before inoculation.

\begin{tabular}{|l|c|c|}
\hline Treatment / Pathogen & \multicolumn{2}{|c|}{ Root fresh weight (g) } \\
\cline { 2 - 3 } & VD & FOL \\
\hline Potassium sorbate (PS) & $14.6 \mathrm{a}$ & $12.8 \mathrm{ab}$ \\
\hline Potassium bicarbonate (PB) & $13.6 \mathrm{a}$ & $10.4 \mathrm{abc}$ \\
\hline Dipotassium hydrophosphate (DPHP) & $10.4 \mathrm{bc}$ & $10.4 \mathrm{ab}$ \\
\hline Inoculated control & $9.8 \mathrm{c}$ & $10.6 \mathrm{ab}$ \\
\hline Uninoculated control & $13.1 \mathrm{ab}$ & $7.4 \mathrm{c}$ \\
\hline
\end{tabular}

'For each pathogen tested, values (means) followed by the same letter are not significantly different according to Duncan's Multiple Range test at $P \leq 0.05$.

Table 7: Effect of potassium salt-based treatments on root fresh weight of tomato cv. Rio Grande plants inoculated with Verticillium dahliae (VD), Fusarium oxysporum $\mathrm{f}$. $\mathrm{sp}$. lycopersici (FOL) and F. oxysporum f. sp. radicis-lycopersici (FORL) noted 60 days post-inoculation under growth chamber conditions.

Potassium sorbate $(0.25 \%, v / v)$, potassium bicarbonate $(50 \mathrm{mM})$ and potassium phosphate $(50 \mathrm{mM})$ were applied as foliar spray five days before inoculation

treated plants and also to that of uninoculated control ones. DPHPtreated plants showed root fresh weight statistically comparable to that of FOL-inoculated and untreated control and also to that of PS- and PB-treated plants but was significantly $34.84 \%$ lower than that of the uninoculated and untreated control.

Root fresh weights noted on PS- and PB-treated plants were statistically comparable and similar to that of uninoculated and untreated control and were increased by $30.76 \%$ and $32.07 \%$, respectively, compared to FORL-inoculated and untreated control. However, foliar application of DPHP led to root fresh weight statistically comparable to FORL-inoculated and untreated control and also to that of other salts but was significantly decreased by $30.76 \%$ if compared to the uninoculated and untreated control.

\section{Aerial part fresh weight}

Aerial part fresh weight noted 60 DPI on PS-, PB- and DPHPtreated plants was significantly (at $P \leq 0.05$ ) similar to that noted on VDinoculated or non-controls (Table 8). PS-treated plants showed $12.71 \%$ increase in aerial part fresh weight, even statistically insignificant, in comparison to VD-inoculated and untreated control. For PS-, PBand DPHP-treated plants, this parameter was significantly (at $P \leq$ $0.05)$ similar to that noted on FOL-inoculated or non-controls. PSbased treatment provided $15.28 \%$ increase in aerial part fresh weight, even statistically insignificant, in comparison to FOL-inoculated and untreated control. However, compared to FORL-inoculated plants, PSbased treatment had significantly augmented aerial part fresh weight by $33.02 \%$ which was statistically similar to that of the uninoculated and untreated control. PB- and DPHP-treated plants showed aerial part fresh weight statistically comparable to both FORL-inoculated and non-controls.

\section{Effect of potassium salts tomato fruit rots severity}

Results shown in Table 9 indicated that on each pathogen-inoculated tomato fruits, potassium salts had significantly $(P \leq 0.05)$ reduced the average lesion diameter, 5 to 7 days after inoculation, compared to the inoculated and untreated controls. DPHP $(0.4 \mathrm{M})$ followed by PS $(0.1 \%, \mathrm{v} / \mathrm{v})$ had significantly $(P \leq 0.05)$ decreased grey mold severity by $46.68 \%$ and $30.81 \%$, respectively, compared to $B$. cinerea-inoculated fruits. However, PB (0.4 M) decreased this parameter by $10.19 \%$, even statistically insignificant, compared to B. cinerea-inoculated control.

Application of PB, DPHP and PS to tomato fruits resulted in significantly $12.83 \%, 14.04 \%$ and $15.74 \%$ lower Rhizoctonia rot severity, respectively, compared to $R$. solani-inoculated fruits.

A significant Anthracnose rot reduction, by $25.24 \%$ and $19.17 \%$ compared to C. coccodes-inoculated fruits, was also achieved 7 days after tomato treatment with PS followed by DPHP, respectively. However, PB-based treatment did not suppress Anthracnose rot where disease severity was statistically comparable to that noted on C. coccodesinoculated control fruits.

PS- and DPHP-treated fruits showed decreased Alternaria rot severity, by $31.67 \%$ and $20 \%$, compared to A. solani-inoculated fruits, while PB-treated fruits showed average lesion diameter statistically comparable to that of the inoculated control.

\section{Discussion}

The findings of the present investigation elucidated the comparative effectiveness of three potassium salts in inhibiting the in vitro growth of wilt-, root rot-, stem decay- and fruit rot-causing tomato pathogens and their relative ability to suppress Verticillium and Fusarium wilts and tomato fruit rots.

The current study highlighted the in vitro antifungal activities of potassium salts against all tomato pathogens tested. Nevertheless, the efficiency of these abiotic agents differed depending on concentrations used and degree of sensitivity of targeted pathogens. For each potassium salt tested, the exact concentration required to inhibit fungal growth differed somewhat between tomato pathogens. These results are consistent with other studies demonstrating that suppression of microbial strains varies in response to different organic and inorganic salts Olivier et al. and Fagundes et al., [17,35] show that the percentage of fungal inhibition in amended PDA medium was dependent on concentration used, and that the most significant decrease in mycelial growth was obtained with the highest concentration of salt tested. 
Citation: Jabnoun-Khiareddine H, Abdallah R, El-Mohamedy R, Abdel-Kareem F, Gueddes-Chahed M, et al. (2016) Comparative Efficacy of Potassium Salts Against Soil-borne and Air-borne Fungi and Their Ability to Suppress Tomato Wilt and Fruit Rots. J Microb Biochem Technol 8: 045055. doi:10.4172/1948-5948.1000261

\begin{tabular}{|c|c|c|c|}
\hline \multirow[t]{2}{*}{ Treatment / Pathogen } & \multicolumn{3}{|c|}{ Aerial part fresh weight $(\mathrm{g})$} \\
\hline & VD & FOL & FORL \\
\hline Potassium sorbate (PS) & $70.8 \mathrm{a}$ & $74.6 \mathrm{a}$ & $64.8 \mathrm{a}$ \\
\hline Potassium bicarbonate (PB) & $62 \mathrm{a}$ & $61.6 \mathrm{a}$ & $56.6 \mathrm{ab}$ \\
\hline Dipotassium hydrophosphate (DPHP) & $61 \mathrm{a}$ & 65 a & $58.6 \mathrm{ab}$ \\
\hline Inoculated control & $61.8 \mathrm{a}$ & $63.2 \mathrm{a}$ & $43.4 \mathrm{~b}$ \\
\hline Uninoculated control & $69.2 \mathrm{a}$ & $72.2 \mathrm{a}$ & $66.2 \mathrm{a}$ \\
\hline
\end{tabular}

'For each pathogen tested, values (means) followed by the same letter are not significantly different according to Duncan's Multiple Range test at $P \leq 0.05$.

Table 8: Effect of potassium salt-based treatments on aerial part fresh weight of tomato cv. Rio Grande plants inoculated with Verticillium dahliae (VD), Fusarium oxysporum f. sp. Iycopersici (FOL) and F. oxysporum f. sp. radicis-lycopersici (FORL) noted 60 days post-inoculation under growth chamber conditions.

Potassium sorbate $(0.25 \%, v / v)$, potassium bicarbonate $(50 \mathrm{mM})$ and potassium phosphate $(50 \mathrm{mM})$ were applied as foliar spray five days before inoculation

\begin{tabular}{|c|c|c|c|c|}
\hline \multirow[b]{2}{*}{ Treatment / Pathogen } & \multicolumn{4}{|c|}{ Average lesion diameter $(\mathrm{cm})$} \\
\hline & B. cinerea & R. solani & C. coccodes & A. solani \\
\hline Potassium sorbate (PS) & $2.92 \mathrm{~b}$ & $3.48 \mathrm{~b}$ & $2.34 \mathrm{c}$ & $2.05 \mathrm{c}$ \\
\hline Potassium bicarbonate (PB) & $3.79 \mathrm{a}$ & $3.6 \mathrm{~b}$ & $2.9 a b$ & $2.84 \mathrm{a}$ \\
\hline Dipotassium hydrophosphate (DPHP) & $2.25 \mathrm{c}$ & $3.55 b$ & $2.53 \mathrm{bc}$ & $2.4 \mathrm{~b}$ \\
\hline Inoculated control & $4.22 \mathrm{a}$ & $4.13 \mathrm{a}$ & $3.13 \mathrm{a}$ & $3 a$ \\
\hline
\end{tabular}

Table 9: Effect of potassium salt-based treatments on the average lesion diameter noted on tomato cv. Sahel fruits inoculated with Botrytis cinerea, Rhizoctonia solani, Colletotrichum coccodes and Alternaria solani.

Potassium sorbate $(0.1 \%, v / v)$, potassium bicarbonate $(0.4 \mathrm{M})$ and potassium phosphate $(0.4 \mathrm{M})$ were applied $6 \mathrm{~h}$ before pathogen-inoculation. Treated fruits were stored at $25^{\circ} \mathrm{C}$ for 5 days post- inoculation with $B$. cinerea and $R$. solani and 7 days for $A$. solani and $C$. coccodes.

In fact, the effectiveness of potassium salts in controlling various plant pathogens have been previously reported [18,36-40]. The mode of action of most salts is postulated to consist in a reduction of fungal turgor pressure that results in the collapse and shrinkage of fungal hyphae causing subsequent inhibition of mycelia growth and sporulation $[23,41]$.

At concentrations ranging from $0.25 \%$ to $1.5 \%$, PS followed by PB $(0.1$ to $0.6 \mathrm{M})$ were found to be more efficient than DPHP $(0.1 \mathrm{M}$ to $0.6 \mathrm{M}$ ) in reducing mycelial growth of the ten tested fungi. In this sense, Mohamedy et al. [42] reported the higher inhibitory effect of PS followed by potassium carbonate against radial growth of several tested fungi (FORL, FOL, F. solani, R. solani, Sclerotium rolfsii, Macrophomina phaseolina, Pythium spp. and Phytophthora spp.) which increased with the increase of concentrations and reached their maximum levels at $4 \%$ and $8 \%$, respectively. Similarly, when studying the in vitro efficacy of eight food additives as possible alternatives to synthetic fungicides for the control of soil-borne pathogens, Arslan U et al., [31] find that the minimum PS inhibitory concentrations are $0.1 \%$ for F. oxysporum f. sp. melonis, $0.2 \%$ for M. phaseolina, $0.6 \%$ for R. solani, and $0.05 \%$ for $S$. sclerotiorum, whereas the minimum fungicidal concentrations were $>2 \%,>2 \%, 0.8 \%$ and $0.1 \%$, respectively. In the same sense, Mecteau et al., [18] showed that the organic anions sorbate completely inhibit mycelial growth of $F$. sambucinum, the causal agent of potato dry rot, at $0.2 \mathrm{M}$, while for spore germination the ED50 was $0.56 \mathrm{mM}$. Sorbate has also shown toxicity on mycelium of Helminthosporium solani, an important potato pathogen and always ranked first in efficacy, since it was fungicidal at concentrations as low as $0.05 \mathrm{M}$ [17]. Sorbate has also shown toxicity on mycelium of Helminthosporium solani, an important potato pathogen and always ranked first in terms of efficacy [17]. PS, which is the most commonly applied salt of sorbic acid, is reported to completely suppress growth of the banana pathogen Colletotrichum musae in vitro when used at $0.125 \%$ [43]. In this regards, Kader et al., [44] noticed that the reduction in mycelial growth of citrus and strawberry fruit decay pathogens (Geotricum candidum, Penicillium digitatum, $P$. italicum and $B$. cinerea) is correlated to the gradual increase in PS concentrations with the highest inhibition observed at $4 \%$. Yildirim et al., found that among food additives, PS shows strong inhibitory against mycelial growth of $B$. cinerea at rising doses [45]. At increasing concentrations (from 600 to $1600 \mu \mathrm{g} / \mathrm{ml}$ ), this salt shows the strongest inhibition on mycelial growth and pycnidia and pycnidiospores production of Phomopsis viticola [46]. In the same sense, Mills et al., also reported that PS has significantly inhibited the growth of B. cinerea, F. solani var. coeruleum, Phytophthora erythroseptica and $P$. infestans infecting potato while $[47,48]$ found that PS has completely suppressed $V$. dahliae growth at $0.25 \%$.

The principle mode of action of weak acid preservatives, such as sorbate, is believed to be the passage of the undissociated compound through the plasma membrane; once inside the cell in a higher $\mathrm{pH}$ environment, the acid dissociates causing an accumulation of protons and anions which cannot re-cross the plasma membrane [49]. In addition, sorbic acid and its salts are known for their ability to alter cell membrane and activity of several enzymes of Krebs cycle [50]. Moreover, sorbate effectively inhibits the growth of moulds, including mycotoxin-producing types, in culture media and in food products [51]. This salt inhibits the production of mycotoxins, including aflatoxins, patulin, citrinin, sterigmatocystin and ochratoxin [52-56].

At the highest dose tested $(0.6 \mathrm{M}), \mathrm{PB}$ was more efficient in halting all pathogens' growth in vitro. Previous studies reported that $\mathrm{PB}$ has significantly inhibited in vitro growth of various plant pathogens [17,31,41,47,57-60]. In this regard, Abdel et al., demonstrated that PB has significantly reduced the linear growth of A. solani, F. solani, $F$. oxysporum and Pythium sp [61]. In the same sense, Punja ZK noted that bicarbonate salt $(\mathrm{PB})$ shows fungicidal effect and prevents sclerotial germination of $S$. rolfsii [57]. Zaker et al., also found that among four inorganic salts tested, $\mathrm{PB}$ performs highest antifungal activity against F. oxysporum, A. alternata and B. cinerea with the best inhibitory effect achieved using $\mathrm{PB}$ at $0.2 \mathrm{M}$. According to study, $\mathrm{KHCO} 3$ is capable of significantly reducing the mycelial growth of $F$. oxysporum by greater than $95 \%$ in Czapek Dox broth at as low as $0.2 \%$ concentration. PB is also reported to inhibit the mycelial growth of $F$. solani by $46.14 \%$ after 7 days of culture in amended PDA $[62,63]$. Recently, Youssef et al., have tested the effect of a novel PB-based formulation and found from in vitro trials a complete inhibition of Penicillium digitatum, $P$. italicum, and $P$. 
ulaiense growth at $0.3,0.3$, and $0.2 \%(\mathrm{w} / \mathrm{v})$, respectively [64]. Similarly, Arslan et al., find that the minimum PB inhibitory concentrations are $>2 \%$ for F. oxysporum f. sp. melonis, $1 \%$ for M. phaseolina, $1.5 \%$ for $R$. solani, and $0.2 \%$ for $S$. sclerotiorum, whereas the minimum fungicidal concentration, $>2 \%$, was the same for all pathogens [31].

Furthermore, bicarbonate salts have been found to have an inhibitory effect on the production of trichothecene mycotoxins in $F$. tricinctum [65], aflatoxins of Aspergillus parasiticus and ochratoxin A of A. ochraceus [66,67].

According to Palmer CL et al., the main mode of action of the bicarbonate ion is through its buffering capacity, whereby an alkaline environment is sustained [41]. When this happens, organisms such as B. cinerea, which require an acidic environment, expend more energy on fungal acid production than hyphal extension and therefore growth may be inhibited. Bicarbonates may also affect membrane permeability and change physiological processes such as oxidative phosphorylation [17]. The inhibition of mycotoxin production by bicarbonate salts has been attributed to their ability to impair the activity of enzymes involved in the biosynthetic pathway for mycotoxins $[65,66]$.

At the highest concentration tested (0.6 M), DPHP was ineffective in halting the mycelial growth of the three Fusarium spp. tested (FOL, FORL and F. solani), C. coccodes and $V$. dahliae, but was efficient in inhibiting growth of $B$. cinerea, $S$. sclerotiorum and P. aphanidermatum. In this sense, Fagundes $C$ et al., verified via in vitro tests that dibasic and tribasic phosphates would decrease colony diameters of $B$. cinerea at rates similar to bicarbonates [35]. Nevertheless, Ordóñez $\mathrm{C}$ et al., mentioned that the efficiency of these compounds depends on concentrations used $(0.2 \%-3 \%)$ and on the relative sensitivity of targeted microorganisms [59]. In this regard, Abdel MM et al., reported that DPHP has significantly limited A. solani, Pythium sp., F. solani and F. oxysporum linear growth and were fungicidal at $4 \%$ [61].

Furthermore, data from our study revealed that P. aphanidermatum, S. sclerotiorum and B. cinerea were the most sensitive pathogens even at lowest salt concentrations. In this sense, Erper I et al., showed that $S$. sclerotiorum could not grow at $100 \mathrm{mM}$ PB while $R$. solani isolate is able to grow even at $500 \mathrm{mM}$ bicarbonate concentration [68]. Similarly, Ordóñez C et al., found that PB exerts significant inhibition on S. sclerotiorum mycelial growth, although either fungus behaved differentially when exposed to the various concentrations of bicarbonate $(2-50 \mathrm{mM})$ [59]. These authors reported that at $50 \mathrm{mM}$, this pathogen was completely inhibited, which indicate its high sensibility to bicarbonate. In the same sense, Olivier et al., reported that isolates of $H$. solani varied in their in vitro response to salt treatments at low concentrations [17]. Mecteau et al., found that F. solani var. coeruleum appears to be particularly sensitive to PS as it is completely inhibited at $0.2 \mathrm{M}[69]$.

Our in vitro results highlighted the broad spectrum of antifungal activity of the three potassium salts tested. In fact, at a given concentration, single salt was able to inhibit the mycelial growth of fungal species belonging to eight different genera and also many species of the same genus. On the other hand, one pathogen could be inhibited by various salts. These results are consistent with many other reports $[17,27,70-72]$. In fact, these salts possess wide-spectrum antimicrobial properties and have been demonstrated to inhibit the growth of several fungal pathogens infecting stored fruits, vegetables, and ornamental species [17,19-22]. To our knowledge, this is the first report on the in vitro antifungal activity of potassium salts against major fungal pathogens of tomato plants in Tunisia.
The in vivo comparative evaluation of PS, PB and DPHP-foliar treatments' ability to suppress Verticillium wilt, Fusarium wilt and FCRR severity clearly showed that these salts varied in their effectiveness against the three tomato diseases. In fact, as shown in the present study, PB-based treatment led to significant decrease in Fusarium wilt and FCRR diseases (by 60.86 and 30\%) and failed to protect plants against Verticillium wilt at the concentration used. Bicarbonate salts, among which $\mathrm{PB}$, have been extensively tested. According to the Environmental Protection Agency in USA (EPA), the use of PB as fungicide could offer a safe alternative to toxic conventional ones as it was not expected to be harmful for humans and the environment [19]. In addition, bicarbonate salts have shown successful management of various postharvest fruit decays as well as foliar diseases and mainly powdery mildew in diverse crops as they exhibit protectant in addition to eradicant activity. However, this is not the case in this study as FOL and FORL are two soil-borne pathogens and there was not any direct contact between these pathogens and PB salt. Hence, the present work gave additional information on the ability of $\mathrm{PB}$ to reduce the severity of two important tomato Fusarium diseases, under growth chamber conditions, although its mode of action needs to be more clarified.

DPHP was able to provide protection against only Fusarium wilt and led to $65.21 \%$ significantly lower disease severity, relative to FOL-inoculated and untreated control. In fact, Deliopoulos et al., reported that among the most studied phosphate salts for their antifungal properties is DPHP which manifests its antifungal activity by induction of systemic acquired resistance (SAR) which requires the signal molecule salicylic acid to be expressed $[19,73]$. In this regards, Biswas SK et al., found that foliar spray of $10 \mathrm{mM}$ DPHP as inducer provides induced resistance against tomato Fusarium wilt, resulting in a decline in the disease incidence to $8.54 \%$ compared to $100 \%$ noted on FOL-inoculated plants at 15 DPI [74]. These results are also in line with Sarwar $\mathrm{N}$ et al., findings that showed that chickpea seed treatment with DPHP reduced Fusarium wilt disease by 30\% [75]. In the same sense, Aleandri MP et al., found that plants grown from seeds treated with the abiotic inducer DPHP at $50 \mathrm{mM}$ become more resistant to Monosporascus cannonballus [34]. In this regard, Sayed SA et al., reported the significant effects of DPHP in reducing the percentages of pre- and post-emergence damping-off caused by R. solani, F. solani and F. oxysporum compared to the control [76]. Furthermore, Lopez et al., found that DPHP reduces the severity of anthracnose disease caused by $C$. gloeosporioides in cashew leaves [77]. The maximum reduction of the disease in detached leaves, without significant phytotoxic effects, is obtained with $50 \mathrm{mM}$ DPHP, with an interval of at least 48 $\mathrm{h}$ between spray application and inoculation. Furthermore, Gottstein HD et al., found that dibasic and tribasic phosphate salts are able to induce systemic resistance to anthracnose of cucumber caused by $C$. lagenarium under greenhouse conditions [78]. The acquired resistance in newly developed leaves remains effective till 5 weeks post-treatments. Hence, in the present study, the observed reduction in Fusarium wilt severity could be due to an induction of systemic acquired resistance.

Single application of PS resulted in 50,78.26, and 65\% lower wilt severity, as respectively compared to VD-, FOL- and FORL-inoculated and untreated controls. In this regards, Mohamedy RSR et al., mentioned that in field trials, the highest reductions of root rot incidence and disease severity caused by F. solani, $R$. solani and S. rolfsii are recorded on tomato plants treated with PS used at 7.5\% and $400 \mathrm{mM}$ DPHP [79]. Indeed, disease incidence and severity are reduced by $65.4 \%$ and $62.5 \%$ in 2012 , and by $63.2 \%$ and $53.8 \%$ in 2013 cropping seasons, respectively. In the same sense, Punja et al., reported that potassium carbonate, PS, and other salts are able to reduce black root rot caused by Chalara 
Citation: Jabnoun-Khiareddine H, Abdallah R, El-Mohamedy R, Abdel-Kareem F, Gueddes-Chahed M, et al. (2016) Comparative Efficacy of Potassium Salts Against Soil-borne and Air-borne Fungi and Their Ability to Suppress Tomato Wilt and Fruit Rots. J Microb Biochem Technol 8: 045055. doi:10.4172/1948-5948.1000261

elegans on carrots [58]. In fact, there is little information available on the use of PS for soil-borne-disease management as most studies are focused on the use of this salt for the control of postharvest diseases of horticultural commodities or as food additives. The present study clearly indicates that PS could give sufficient control of three important tomato soil-borne diseases; nevertheless, more information on its antifungal activities needs to be elucidated.

Because most of the literature about potassium salts applications has focused on controlling foliar or postharvest diseases $[19,23,80]$, there is little information on the effects of these salts on the promotion of tomato growth after challenge with soil-borne pathogens such as $V$. dahliae, FOL and FORL. Hence, important findings from our study revealed that foliar sprays of PS five days before pathogen challenge could enhance more than one tomato growth parameter in more than one pathosystem. In fact, this salt had significantly increased plant height, root and aerial part fresh weights by $20.61 \%, 30.76 \%$ and $33.02 \%$, respectively, compared to FORL-inoculated plants and had also improved root fresh weight by $42.18 \%$ and $32.87 \%$ compared to FOLand VD-inoculated plants, respectively. However, DPHP treatment had significantly augmented plant height by $9.5 \%$ as compared to FORLinoculated plants, whereas, PB-foliar application resulted in $27.94 \%$ increase in root fresh weight relative to VD-inoculated plants. These findings are in line with Mohamedy et al., studies who revealed that among various chemical resistance inducers tested, PS and DPHP have positive effects on plant growth, yield and fruit quality of tomato plants grown under naturally field infested by root rot diseases caused by $R$. solani, F. solani and S. rolfsii, during two cropping seasons [79].

This study highlighted also the potential use of potassium salts for postharvest disease control of fresh tomatoes. In fact, our results indicated that DPHP and PS had significantly decreased grey mold, Rhizoctonia, Alternaria and Anthracnose fruit rots by 46.68 and $30.81 \%, 14.04$ and $15.74 \%, 20$ and $31.67 \%$ and 19.17 and $25.24 \%$ respectively, compared to $B$. cinerea-, $R$. solani-, C. coccodes-, and A. solani-inoculated control fruits. However, application of $\mathrm{PB}$ to tomato fruits resulted in significant decrease of Rhizoctonia rot by $12.83 \%$. In fact, different salts have been evaluated for the control of postharvest decay of tomatoes and other stored fruits. The application of PS, sodium benzoate and sodium EDTA were reported to effectively control oranges post-harvest molds caused by Penicillium digitatum and P. italicum $[30,81]$.

In the present study, PS and DPHP were fund to be the most efficient in reducing all tomato fruit rots. In this sense, Mehyar GF et al., reported that Guar gum edible coating incorporated with PS is the most effective mold inhibitor, in significantly reducing the isolated spoilage molds for 20,15 , and 20 days of storage at $4^{\circ} \mathrm{C}$ on apples, cucumbers, and tomatoes, respectively [82]. In the same sense, Palou L et al., studied the inhibition effect of a wide range of food additives and GRAS substances alone and in mixtures against $P$. digitatum- and $P$. italicum-inoculated on orange and lemon, and reported that PS is among the most effective compounds tested in decreasing P. digitatum viable population by $70 \%$ to $80 \%$ [30]. In another study, PS exhibits the greatest antimicrobial activity out of 8 food additives tested to inhibit growth of several food-borne pathogens [31]. In addition, these salts have potential as environmentally compatible, nontoxic postharvest fungicides and have very low levels of mammalian toxicity (For example, for $\mathrm{PS}, \mathrm{LD}_{50}$ in rat: 4-7 $\mathrm{g} / \mathrm{kg}$ body weight, equals $500 \mathrm{~g}$ for an adult human) [17].

However, $\mathrm{PB}$ was found to be ineffective against most tomato fruit rot pathogens even though bicarbonates were reported possess wide-spectrum antimicrobial properties; their efficacy in controlling postharvest fungal phytopathogens has been widely reported $[17,20$ $22,35,37,41,80]$

Overall, differences in effectiveness of potassium salts between in vitro and in fruit trials have been observed in this study. The direct inhibitory effect of the salts amended in PDA on the growth of $B$. cinerea or A. solani, C. coccodes and A. solani in Petri dishes differ considerably from the inhibitory ability of these salts to control these pathogens when applied to tomato fruits.

\section{Conclusion}

In this study, it was observed that potassium salts tested possess variable antifungal activity in vitro depending on fungal tomato pathogens tested and concentrations used. They were shown to have direct antifungal potential and also indirect effect by decreasing tomato wilt severity incited by FOL, FORL and VD and by enhancing growth. Based on these findings, it could be concluded that, when applied as foliar spray, PS used at $0.25 \%$ followed by PB applied at $50 \mathrm{mM}$ may markedly suppress Verticillium wilt, Fusarium wilt, and Fusarium Crown and Root Rot severities and enhance tomato plant growth. Further studies are needed to more elucidate the exact mechanism deployed by these salts via different modes and timings of application. On fruits, PS followed by DPHP was more effective in reducing all pathogen-causing rots than $\mathrm{PB}$. It can be concluded that inorganic salt treatments could be a very useful component of integrated disease management strategies.

\section{References}

1. Hibar K, Daami-Remadi M, El-Mahjoub M (2007) Induction of resistance in tomato plants against $\mathrm{f}$. sp. radicis-lycopersici by Trichoderma spp. Tunisian J Plant Prot 2: 47-58.

2. Jabnoun H, Daami M, Ayed F, El Mahjoub M (2009) Biocontrol of tomato Verticillium wilt by using indigenous Gliocladium spp. and Penicillium sp. isolates. Dynamic Soil, Dynamic Plant 3: 70-79.

3. Jabnoun $\mathrm{H}$, Mohamedy R, Kareem F, Abdallah R, Chahed M, et al. (2015) Variation in chitosan and salicylic acid efficacy towards soil-borne and airborne fungi and their suppressive effect of tomato wilt severity. J Plant Pathol Microbiol 6: 325.

4. Hawke MA, Lazarovits G (1994) Production and manipulation of individua microsclerotia of Verticillium dahliae for use in studies of survival. Phytopathology 84: 883-890.

5. Fradin EF, Thomma BP (2006) Physiology and molecular aspects of Verticillium wilt diseases caused by V. dahliae and V. albo-atrum. Mol Plant Pathol 7: 71-86.

6. Pietro AD, Madrid MP, Caracuel Z, Delgado-Jarana J, Roncero MI (2003) Exploring the molecular arsenal of a vascular wilt fungus. Mol Plant Pathol 4 315-325.

7. Ignjatov M, Miloševi D, Nikoli Z, Gvozdanovi J, Jovi D, et al. (2012) as causal agent of tomato wilt and fruit rot. Pestic Phytomed 27: 25-31.

8. Anonymous (2015) Groupement Interprofessionnel des légumes, filières des legumes.

9. Dobinson KF, Tenuta GK, Lazarovits G (1996) Occurrence of race 2 of Verticillium dahliae in processing tomato fields in southwestern Ontario. Can J Plant Pathol 18: 55-58.

10. Reis A, Costa H, Boiteux LS, Lopes CA (2005) First report of f. sp. lycopersici race 3 on tomato in Brazil. Fitopatol Bras 30: 426-428.

11. Amini J, Sidovich DF (2010) The effect of fungicides on f. sp. Iycopersic associated with Fusarium wilt tomato. J Plant Prot Res 50: 172-178.

12. Daami M, Jabnoun H, Barbara DJ, Ayed F, Mahjoub M (2006) First report of Verticillium dahliae race 2 in Tunisia. Plant Pathol 55: 816.

13. Uppal AK, Hadrami A, Adam LR, Tenuta M, Daayf F (2007) Pathogenic variability of Verticillium dahliae isolates from potato fields in Manitoba and screening of bacteria for their biocontrol. Can J Plant Pathol 29: 141-152. 
Citation: Jabnoun-Khiareddine H, Abdallah R, El-Mohamedy R, Abdel-Kareem F, Gueddes-Chahed M, et al. (2016) Comparative Efficacy of Potassium Salts Against Soil-borne and Air-borne Fungi and Their Ability to Suppress Tomato Wilt and Fruit Rots. J Microb Biochem Technol 8: 045055. doi:10.4172/1948-5948.1000261

14. Hassine M, Abdallah R, Khiareddine $H$, Jannet $H$, Remadi M (2013) Effet des températures d'incubation et des méthodes de confrontation sur le pouvoir inhibiteur exercé par Penicillium sp. et Gliocladium spp. sur Botrytis cinerea. Tunis J Med Plants Nat Prod 9: 41-51.

15. Hassine M, Abdallah R, Khiareddine H, Remadi M (2014) Pouvoir antifongique des Penicillium sp. et des Gliocladium spp. contre Alternaria solani in vitro et sur fruits de tomate. Tunis J Med Plants Nat Prod 12: 9-28.

16. Horst RK, Kawamoto SO, Porter LL (1992) Effect of sodium bicarbonate and oils on the control of powdery mildew and black spot of roses. Plant Dis 76 : 247-251.

17. Olivier C, Halseth DE, Mizubuti E, Loria R (1998) Postharvest application of organic and inorganic salts for suppression of silver scurf on potato tubers. Plant Dis 82: 213-217.

18. Mecteau MR, Arul J, Tweddell RJ (2002) Effect of organic and inorganic salts on the growth and development of Fusarium sambucinum, a causal agent of potato dry rot. Mycol Res 106: 688-696.

19. Deliopoulos T, Kettlewell PS, Hare MC (2010) Fungal disease suppression by inorganic salts: A review. Crop Prot 29: 1059-1075.

20. Palou L, Smilanick JL, Usall J, Vinas I (2001) Control of postharvest blue and green molds of oranges by hot water, sodium carbonate, and sodium bicarbonate. Plant Dis 85: 371-376.

21. Karabulut OA, Smilanick JL, Mlikota Gabler F, Mansour M, Droby S (2003) Near harvest applications of Metschnikowia fructicola, ethanol, and sodium bicarbonate to control postharvest diseases of grape in central California. Plan Dis 87: $1384-1389$

22. Arslan U, Ilhan K, Karabulut OA (2006) Evaluation of food additives and low toxicity compounds for the control of bean rust and wheat leaf rust. $J$ Phytopathol 154: 534-541.

23. Fallik E, Ziv O, Grinberg S, Alkalai S, Klein JD (1997) Bicarbonate solutions control powdery mildew (Leveillula taurica) on sweet red pepper and reduce the development of postharvest fruit rotting. Phytoparasitica 25: 41-43.

24. Greenway DL (1999) Potassium Bicarbonate (073508) and Sodium Bicarbonate (073505) Fact Sheet. Environmental Protection Agency, Washington, DC.

25. Ziv O, Zitter TA (1992) Effects of bicarbonates and film-forming polymers on cucurbit foliar diseases. Plant Dis 76: 513-517.

26. HDC (Horticultural Development Company) (2005) Use of Potassium Hydrogen Carbonate for Powdery Mildew Control. Final Report on HDC Project CP48, HDC, East Malling, UK

27. Reuveni M, Agapov V, Reuveni R (1996) Controlling powdery mildew caused by Sphaerotheca fuliginea in cucumber by foliar sprays of phosphate and potassium salts. Crop Prot 15: 49-53.

28. Sofos JN, Busta FF (1981) Antimicrobial activity of sorbate. J Food Protect 44 614-622.

29. Suhr KI, Nielsen PV (2004) Effect of weak acid preservatives on growth of bakery product spoilage fungi at different water activities and $\mathrm{pH}$ values. Int $J$ Food Microbiol 95: 67-78.

30. Palou L, Usall J, Smilanick JL, Aguilar MJ, Viñas I (2002) Evaluation of food additives and low-toxicity compounds as alternative chemicals for the contro of Penicillium digitatum and Penicillium italicum on citrus fruit. Pest Manag Sci 58: 459-466.

31. Arslan U, Ilhan K, Vardar C, Karabulut OA (2009) Evaluation of antifungal activity of food additives against soil-borne phytopathogenic fungi. World $\mathrm{J}$ Microbiol Biotechnol 25: 537-543.

32. Pharand B, Carisse O, Benhamou N (2002) Cytological aspects of compostmediated induced resistance against fusarium crown and root rot in tomato. Phytopathology 92: 424-438.

33. Tiru M, Muleta D, Bercha G, Adugna G (2013) Antagonistic effect of rhizobacteria against coffee wilt disease caused by Gibberella xylarioides. Asian J Plant Pathol 7: 109-122.

34. Aleandri MP, Reda R, Tagliavento V, Magro P, Chilosi G (2010) Effect of chemical resistance inducers on the control of Monosporascus root rot and vine decline of melon. Phytopathol Medit 49: 18-26.

35. Fagundes C, Pérez MB, Monteiro AR, Palou L (2013) Antifungal activity of food additives in vitro and as ingredients of hydroxypropyl methylcelluloselipid edible coatings against Botrytis cinerea and Alternaria alternata on cherry tomato fruit. Int J Food Microbiol 166: 391-398.
36. Türkkan M, Erper (2015) Inhibitory influence of organic and inorganic sodium salts and synthetic fungicides against bean root rot pathogens. Gesunde Pflanzen 67: 83-94.

37. Nigro F, Schena L, Ligorio A, Pentimone I, Ippolito A, et al. (2006) Control of table grape storage rots by pre-harvest applications of salts. Postharvest Biol Technol 42: 42-149.

38. Palou L, Smilanick JL, Droby S (2008) Alternatives to conventional fungicides for the control of citrus post-harvest green and blue molds. Stewart Postharvest Review 2:1-16

39. Palou L, Smilanick JL, Crisosto CH (2009) Evaluation of food additives as alternative or complementary chemicals to conventional fungicides for the control of major postharvest diseases of stone fruit. J Food Prot 72: 1037-1046.

40. Youssef K, Sanzani SM, Ligorio A, Ippolito A, Terry LA (2014) Sodium carbonate and bicarbonate treatments induce resistance to postharvest green mold on citrus fruit. Postharvest Biol Technol 87: 61-69.

41. Palmer CL, Horst RK, Langhans RW (1997) Use of bicarbonates to inhibit in vitro colony growth of Botrytis cinerea. Plant Dis 81: 1432-1438.

42. Mohamedy SR, Kader MM, Kareem F, Mougy NS (2013) Essential oils inorganic acids and potassium salts as control measures against the growth of tomato root rot pathogens in vitro. International Journal of Agricultural Technology 9: 1507-1520.

43. Zaemey AB, Magan N, Thompson AK (1993) Studies on the fruit coating polymers and organic acid on growth of Colletotrichum musae in vitro and postharvest control of anthracnose of bananas. Mycol Res 97: 1463-2468.

44. Kader M, Mougy N, Lashin S (2011) Evaluation of grapefruit coating with chemical preservatives as control measure against post-harvest decay. Phytopathologia 59: 25-38.

45. Yildirim I, Yapici BM (2007) Inhibition of conidia germination and mycelia growth of Botrytis cinerea by some alternative chemicals. Pak J Biol Sci 10 1294-1300.

46. Yildirim (2014) Influence of some food additive chemicals to Phomopsis viticola Sacc. Review on Agriculture and Rural Development 3: 228-234

47. Mills S, Platt HW, Hurta R (2004) Effect of salt compounds on mycelial growth, sporulation and spore germination of various potato pathogens. Post-harvest Biol Technol 34: 341-350.

48. Youssef A, Rehab A, Ghany M (2014) Preliminary investigation of Verticillium wilt on mango trees (Mangifera indica L.) in Egypt. Am-Eur j Sust Agric 8: 50-58.

49. Brul S, Coote P (1999) Preservative agents in foods. Mode of action and microbial resistance mechanisms. Int J Food Microbiol 50: 1-17.

50. Olivier C, Macniel CR, Loria R (1999) Application of organic and inorganic salts to field-grown potato tubers can suppress silver scurf during potato storage. Plant Dis 83: 814-818.

51. Liewen MB, Marth EH (1984) Inhibition of Penicillia and Aspergilli by potassium sorbate. J Food Prot 47: 554-556

52. Bhattachrya M, Majumdar SK (1984) Effect of some antifungal compounds on growth of Penicillium citrinum and citrinin production. J Food Sci Technol 21 : $38-40$

53. Bullerman LB (1985) Effects of potassium sorbate on growth and ochratoxin production by Aspergillus ochraceus and Penicillium species. J Food Prot 48:162-165.

54. Lennox JE, McElroy LJ (1984) Inhibition of growth and patulin synthesis in Penicillium expansum by potassium sorbate and sodium propionate in culture. Appl Environ Microbiol 48: 1031-1033.

55. Tsai WYJ, Shao LB (1984) Effects of sorbate and propionate on growth and aflatoxin production by sublethally injured Aspergillus parasiticus. J Food Sci 49: 86-90.

56. Tong $\mathrm{CH}$, Draughon FA (1985) Inhibition by antimicrobial food additives of ochratoxin A production by Aspergillus sulphureus and Penicillium viridicatum. Appl Environ Microbiol 49: 1407-1411.

57. Punja ZK, Grogan RG (1982) Effects of inorganic salts, carbonate bicarbonate anions, ammonia, and the modifying influence of $\mathrm{pH}$ on sclerotial germination of Sclerotium rolfsii. Phytopathology 72: 635-639.

58. Punja ZK, Gaye MM (1993) Influence of postharvest handling practices and 
Citation: Jabnoun-Khiareddine H, Abdallah R, El-Mohamedy R, Abdel-Kareem F, Gueddes-Chahed M, et al. (2016) Comparative Efficacy of Potassium Salts Against Soil-borne and Air-borne Fungi and Their Ability to Suppress Tomato Wilt and Fruit Rots. J Microb Biochem Technol 8: 045055. doi:10.4172/1948-5948.1000261

dip treatments on development of black root rot on fresh market carrots. Plant Dis 77: 989-995

59. Ordóñez C, Alarcón A, Ferrera R, Hernández V (2009) In vitro antifungal effects of potassium bicarbonate on Trichoderma sp. and Sclerotinia sclerotiorum. Mycoscience 50: 380-387.

60. Samapundo S, Devlieghere F, De Meulenaer B, Lamboni Y, Osei-Nimoh D, et al. (2007) Interaction of water activity and bicarbonate salts in the inhibition of growth and mycotoxin production by Fusarium and Aspergillus species of importance to corn. Int J Food Microbiol 116: 266-274.

61. Abdel MM, El NS, Gammal NG, Abd F, Abd A (2012) Laboratory evaluation of some chemicals affecting pathogenic fungal growth. J Appl Sci Res 8: 523-530.

62. Zaker M (2014) Antifungal evaluation of some inorganic salts against three phytopathogenic fungi. Int J Agri Crop Sci 7: 1352-1358.

63. Hang YD, Woodams EE (2003) Control of by baking soda. Food Sci Techno 36: 803-805

64. Youssef K, Sanzani SM, Myrta A, Ippolito A (2014) Effect of a novel potassium bicarbonate-based formulation against Penicillium decay of oranges. J Plant Pathol 96: 419-424.

65. Roinestad KS, Montville TJ, Rosen JD (1994) The mechanism of inhibition of tricothecene biosynthesis in Fusarium tricinctum by sodium bicarbonate. $J$ Agric Food Chem 2025-2028.

66. Nabarawy A, Hartman T, Rosen JD, Montville, TJ (1989) Aspergillus parasiticus accumulates averufin and versicolorin $\mathrm{A}$ in the presence of bicarbonate. $\mathrm{J}$ Food Prot 52: 493-495.

67. Montville TJ, Goldstein PK (1987) Sodium bicarbonate reduces viability and alters aflatoxin distribution of Aspergillus parasiticus in Czapek's agar. Appl Environ Microbiol 53: 2303-2307.

68. Erper I, Turkkan M, Karaca GH (2011) Evaluation of in vitro antifungal activity of potassium bicarbonate on Rhizoctonia solani AG 4 HG-I, Sclerotinia sclerotiorum and Trichoderma sp. Afr J Biotechnol 10: 8605-8612.

69. Mecteau MR, Arul J, Tweddell RJ (2008) Effect of different salts on the development of Fusarium solani var. coeruleum, a causal agent of potato dry rot. Phytoprotection 89: 1-6.

70. Reuveni R, Dor G, Reuveni M (1998) Local and systemic control of powdery mildew (Leveillula taurica) on pepper plants by foliar spray of mono-potassium phosphate. Crop Prot 17: 703-709.
71. Hervieux V, Yaganza ES, Arul J, Tweddell RJ (2002) Effect of organic and inorganic salts on the development of Helminthosporium solani, the causa agent of potato silver scurf. Plant Dis 86: 1014-1018.

72. Yildirim I, Onogur E, Irshad M (2002) Investigations on the efficacy of some natural chemicals against powdery mildew (Uncinula necator (Schw.) Burr.) of grape. J Phytopathol 150: 697-702.

73. Walters D, Walsh D, Newton A, Lyon G (2005) Induced resistance for plant disease control: maximizing the efficacy of resistance elicitors. Phytopathology 95: 1368-1373.

74. Biswas SK, Pandey NK, Mohd R (2012) Inductions of defense response in tomato against Fusarium wilt through inorganic chemicals as inducers. J Plant Pathol Microbiol 3: 1-7.

75. Sarwar N, Zahid MHC, Haq I (2010) Seed treatments induced systemic resistance in chickpea against Fusarium wilt in wilt sick field. Pak J Bot 42: 3323-3326.

76. Sayed SA, Mousa AM (2015) Production, effect of some algal filtrates and chemical inducers on root-rot incidence of faba bean. Agri Res Tech $\mathrm{J} 1$ : 555552 .

77. Lopez Q (2002) Effects of plant defence activators on anthracnose disease of cashew. Eur J Plant Pathol 108: 409-420.

78. Gottstein HD, Kuc JA (1989) Induction of systemic resistance to anthracnose in cucumber by phosphates. Phytopathology 79: 176-179.

79. Mohamedy RSR, Khiareddine H, Remadi M (2014) Control of root rot diseases of tomato plants caused by Fusarium solani, Rhizoctonia solani and Sclerotium rolfsii using different chemical plant resistance inducers. Tunisian J Plant Prot 9: 45-55.

80. Bombelli, EC, Wright ER (2006) Tomato fruit quality conservation during postharvest by application of potassium bicarbonate and its effect on Botrytis cinerea. Ciencia e Investigacion Agraria 33: 167-172.

81. Chamorro SA, Palou L, del MA, Pérez-Gago MB (2008) Inhibition of Penicillium digitatum and Penicillium italicum by hydroxypropyl methylcellulose lipid edible composite films containing food additives with antifungal properties. J Agric Food Chem 56: 11270-11278.

82. Mehyar GF, Qadiri HM, Blan HA, Swanson BG (2011) Antifungal effectiveness of potassium sorbate incorporated in edible coatings against spoilage molds of apples, cucumbers, and tomatoes during refrigerated storage. J Food Sci 76: $210-217$ 